Article

\title{
Low-Temperature Oxidation Removal of Formaldehyde Catalyzed by Mn-Containing Mixed-Oxide-Supported Bismuth Oxychloride in Air
}

\author{
Xiaoli Wang ${ }^{1, *}$, Gongde $\mathrm{Wu}^{2, *}$ and Yanwen $\mathrm{Ma}^{3, *}$ \\ 1 School of Environment and Technology, Nanjing Institute of Technology, Nanjing 211167, China \\ 2 Energy Research Institute, Nanjing Institute of Technology, Nanjing 211167, China \\ 3 Key Laboratory for Organic Electronics and Information Displays, Institute of Advanced Materials, \\ Nanjing University of Posts and Telecommunications, Nanjing 210023, China \\ * Correspondence: wangxiaoli212@njit.edu.cn (X.W.); wugongde@njit.edu.cn (G.W.); \\ amywma@njupt.edu.cn (Y.M.)
}

check for updates

Citation: Wang, X.; Wu, G.; Ma, Y.

Low-Temperature Oxidation

Removal of Formaldehyde Catalyzed

by Mn-Containing

Mixed-Oxide-Supported Bismuth

Oxychloride in Air. Catalysts 2022, 12,

262. https://doi.org/10.3390/

catal12030262

Academic Editors: Ioan-Cezar Marcu and Octavian Dumitru Pavel

Received: 15 January 2022

Accepted: 22 February 2022

Published: 25 February 2022

Publisher's Note: MDPI stays neutral with regard to jurisdictional claims in published maps and institutional affiliations.

Copyright: () 2022 by the authors. Licensee MDPI, Basel, Switzerland. This article is an open access article distributed under the terms and conditions of the Creative Commons Attribution (CC BY) license (https:// creativecommons.org/licenses/by/ $4.0 /)$.

\begin{abstract}
The Mn-containing mixed-oxide-supported bismuth oxychloride (BiOCl) catalysts were prepared by calcining their corresponding parent hydrotalcite supported BiOCl. The crystal structure of $\mathrm{BiOCl}$ was found to be intact during calcination, while significant differences appeared in the chemical state of $\mathrm{Mn}$ and the redox capacities of the catalysts before and after calcination. Compared to the hydrotalcite-supported catalysts, the mixed-oxide-supported $\mathrm{BiOCl}$ showed much higher catalytic performance in the oxidation removal of formaldehyde due to the synergetic catalysis of more surface oxygen vacancies and higher surface basicity. The complete removal of formaldehyde could be achieved at $70{ }^{\circ} \mathrm{C}$, and the removal efficiency was maintained more than $90 \%$ for $21 \mathrm{~h}$. A possible reaction mechanism was also proposed.
\end{abstract}

Keywords: formaldehyde; oxidation removal; BiOCl; mixed oxides; manganese

\section{Introduction}

Among volatile organic pollutants (VOCs), formaldehyde is one of the most harmful gases with the widest sources. As early as 2004, formaldehyde was listed as the first carcinogen by the international agency for research on cancer (IARC) [1-3]. In order to eliminate the harm of formaldehyde to human health, researchers from all over the world have carried out a lot of work, and many formaldehyde removal technologies have been developed, such as adsorption, photocatalysis, low-temperature plasma and catalytic oxidation [4-7]. Among them, catalytic oxidation can completely decompose formaldehyde into harmless $\mathrm{CO}_{2}$ and $\mathrm{H}_{2} \mathrm{O}$ without secondary pollution, and thus is considered the most effective method [4-7]. Especially the effective removal of formaldehyde by catalytic oxidation under the condition of natural air atmosphere and low temperature shows more practical significance and application prospect [8]. Additionally, the key of this technology is to design efficient catalysts and catalytic systems.

When it comes to the reported catalysts for the oxidation removal of formaldehyde, noble metal catalysts were represented by Pt or Au catalysts [9-15], while transition metal catalysts were mainly Mn or Co catalysts [16-19]. Owing to the low cost and rich resources, the transition metal catalysts, especially transition metal oxides, had attracted much attention in academia and industry. Among them, manganese oxides usually exhibited excellent catalytic performance in the removal reaction of formaldehyde than the other transition metal oxides, such as $\mathrm{CoO}, \mathrm{TiO}_{2}$ and $\mathrm{CeO}_{2}$ [20-24]. This might be because manganese oxides could mobilize electrons and generate the mobile-electron environment, which is exactly needed by oxidation removal reaction of formaldehyde due to the variable oxidation states of $\mathrm{Mn}$ from -3 to +7 . A series of effective manganese oxides with different 
valences, structures, morphology and matrixes had been prepared and widely used as catalysts. Rong et al. impregnated PET into ultrathin $\mathrm{MnO}_{2}$ nanosheets, and the obtained $\mathrm{MnO}_{2} / \mathrm{PET}$ catalyst could remove formaldehyde by oxidation with a removal efficiency of $81 \%$ at room temperature. The impregnation of PET was thought to benefit the formaldehyde adsorption and removal [25]. Bai et al. prepared a three-dimensional (3D) ordered mesoporous $\mathrm{MnO}_{2}$ using KIT-6 mesoporous molecular sieves as a hard template. Complete conversion of formaldehyde was achieved at $130{ }^{\circ} \mathrm{C}$, which was attributed to the specific mesoporous structure, high specific surface area and a large number of surface $\mathrm{Mn}^{4+}$ ions [26]. $\mathrm{Ag} / \mathrm{MnO}_{2}$ was also further synthesized for catalytic removal of formaldehyde, and complete removal efficiency was achieved at $100^{\circ} \mathrm{C}$ due to the synergetic catalysis of $\mathrm{Ag}$ nanoparticles and three-dimensional ordered mesoporous $\mathrm{MnO}_{2}$ supports [27]. Clearly, high removal efficiency and low reaction temperature were a research direction of formaldehyde removal reaction. Besides single manganese oxide catalysts, several binary or ternary Mn-containing mixed oxides were found to be more active in the oxidation removal of formaldehyde. Zhu et al. found that $\mathrm{MnO}_{x} \mathrm{CeO}_{2}$ composite catalyst with the nominal $\mathrm{Ce} / \mathrm{Mn}$ ratio of 1:10 exhibited the best activity and achieved complete formaldehyde conversion at $100{ }^{\circ} \mathrm{C}$ [28]. Huang et al. discovered that $\mathrm{Co}_{x} \mathrm{Mn}_{3-\mathrm{x}} \mathrm{O}_{4}$ nanosheet catalysts showed substantially higher catalytic activity for formaldehyde oxidation, and complete conversion of formaldehyde also appeared at $100{ }^{\circ} \mathrm{C}$ [29]. O'Shea reported that $\mathrm{PdMnO} / \mathrm{Al}_{2} \mathrm{O}_{3}$ could completely catalytically oxidize the mixture of formaldehyde and methanol at $70{ }^{\circ} \mathrm{C}$ [30]. It was generally accepted that the introduction of the second or third metal oxides could influence the crystallization process of mixed oxides, which would induce a decrease in the particle sizes and an increase in the surface area. This might afford the enhanced catalytic performance of mixed oxides in the removal reaction of formaldehyde in comparison with the single manganese oxide. The previous studies proved that the Mn-containing mixed oxides were promising catalysts or catalyst supports for the removal of formaldehyde.

On the other hand, $\mathrm{BiOX}(\mathrm{X}=\mathrm{Cl}, \mathrm{Br}, \mathrm{I})$ is a kind of layered semiconductor with high anisotropy, and its light absorption capacity can be regulated by changing the type and content of halogen elements. In particular, $\mathrm{BiOCl}$ with high thermal stability had been used wildly in photocatalytic degradation of organic pollutants to $\mathrm{CO}_{2}, \mathrm{H}_{2} \mathrm{O}$ and other inorganic small molecules [31,32]. Our consistent interests in the design of heterogeneous catalysts and the removal of organic pollutants pushed us to combine the catalytic characteristics of Mn-containing mixed oxides and BiOCl.

In our previous report, we had found that $\mathrm{CuNiAl}-\mathrm{HT}$ supported $\mathrm{BiOCl}$ exhibited effective catalytic performance in the selective oxidation of glycerol by $3 \% \mathrm{H}_{2} \mathrm{O}_{2}$ [33]. Inspired by this work, in view of characteristics and catalytic requirements of the formaldehyde removal reaction, we tried to load active $\mathrm{BiOCl}$ on the Mn-containing mixed oxides that were usually thought to be active for the complete oxidation reaction. The catalytic performance and stability of the obtained catalysts in the oxidation removal of formaldehyde were investigated, and the structure-activity relationship of catalysts and reaction mechanisms were also discussed.

\section{Results}

\subsection{Characterization of Catalysts}

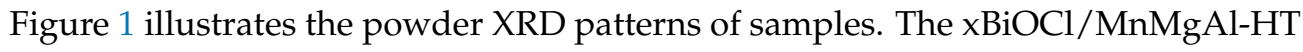
showed typical hydrotalcite-like reflections of (003), (006) and (110) planes and BiOCl reflections of (101), (110) and (102) planes [31-35] (see Figure 1A). Moreover, with the increase in the loading amount of $\mathrm{BiOCl}$, the intensity of the characteristic reflections assigned to $\mathrm{BiOCl}$ strengthened, while no significant change was found in the hydrotalcite-like reflections. As expected, there was no significant difference in the XRD patterns of $0.01 \mathrm{BiOCl} / \mathrm{MnMgAl}-$ $\mathrm{HT}$ and $0.012 \mathrm{BiOCl} / \mathrm{MnMgAl}-\mathrm{HT}$ due to the small difference in $\mathrm{BiOCl}$ content. Thus, for the purpose of simplification, $0.012 \mathrm{BiOCl} / \mathrm{MnMgAl}-\mathrm{HT}$ did not appear in the following characterization figures. After calcination, it was found that the characteristic peaks of hydrotalcite-like almost disappeared, while the $\mathrm{BiOCl}$ reflections were still present clearly 
(see Figure $1 \mathrm{~B}$ ), suggesting that the crystal structure of $\mathrm{BiOCl}$ was intact during calcination. Simultaneously, two new peaks at about $43^{\circ}$ and $63^{\circ}$ associated with the MgAl mixed oxides were also detected. This indicated that the layered structure of the hydrotalcite-like matrix was destroyed, and the new phases of mixed oxides appeared during calcination. No significant manganese oxides crystalline phase was present, probably because of their amorphous state. In addition, for $0.015 \mathrm{BiOCl} / \mathrm{MnMgAlO}$, some weak reflections of $\mathrm{Bi}_{2} \mathrm{O}_{3}$ were also detected, which were absent in the other samples, might originate from the decomposition of excessive $\mathrm{BiOCl}$ during calcination.
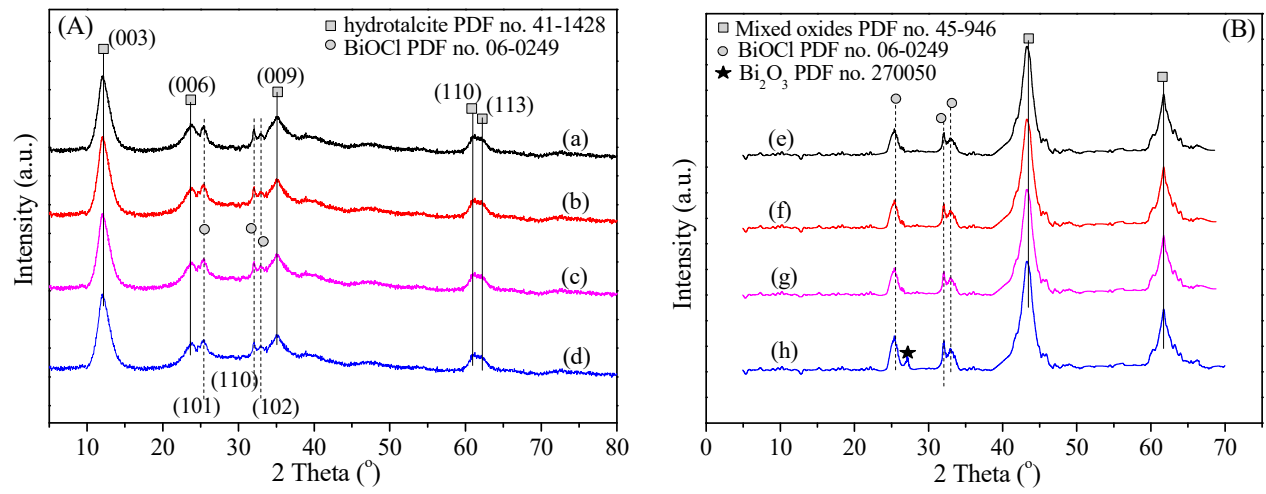

Figure 1. XRD patterns of (A) $\mathrm{xBiOCl} / \mathrm{MnMgAl}-\mathrm{HT}$ and (B) $\mathrm{xBiOCl} / \mathrm{MnMgAlO}$ (a) $0.005 \mathrm{BiOCl} / \mathrm{MnMgAl}-\mathrm{HT}$, (b) $0.01 \mathrm{BiOCl} / \mathrm{MnMgAl}-\mathrm{HT}$ ， (c) $0.012 \mathrm{BiOCl} / \mathrm{MnMgAl}-\mathrm{HT}$, (d) $0.015 \mathrm{BiOCl} / \mathrm{MnMgAl}-\mathrm{HT}$, (e) $0.005 \mathrm{BiOCl} / \mathrm{MnMgAlO}$, (f) $0.01 \mathrm{BiOCl} / \mathrm{MnMgAlO}$ and (g) $0.012 \mathrm{BiOCl} / \mathrm{MnMgAlO}$, (h) $0.015 \mathrm{BiOCl} / \mathrm{MnMgAlO}$.

The $\mathrm{N}_{2}$ adsorption/desorption isotherms of $x \mathrm{BiOCl} / \mathrm{MnMgAl}-\mathrm{HT}$ and $\mathrm{xBiOCl} / \mathrm{MnMgAlO}$ in Figure 2 all showed type IV isotherms, indicating that mesoporous structure had been formed due to the aggregation of particles. For the three hydrotalcite-supported $\mathrm{BiOCl}$ catalysts, compared to pure hydrotalcite, a significant decrease was found in their surface area (see Table 1). Moreover, with the increase in the loading amount of $\mathrm{BiOCl}$, the surface area of supported catalysts decreased continually, probably because of the increased pore lock phenomenon derived from the introduction of $\mathrm{BiOCl}$. A similar trend also appeared in the three mixed-oxide-supported $\mathrm{BiOCl}$ catalysts, and the increased loading of $\mathrm{BiOCl}$ to Mn-containing mixed oxides also led to a significantly decreased surface area. Noticeably, the lowest surface area of $0.015 \mathrm{BiOCl} / \mathrm{MnMgAlO}$ was found in comparison with the other two mixed-oxide-supported catalysts. This might be associated with the appearance of $\mathrm{Bi}_{2} \mathrm{O}_{3}$ with a larger molecular size than $\mathrm{BiOCl}$, as described in XRD characterization.

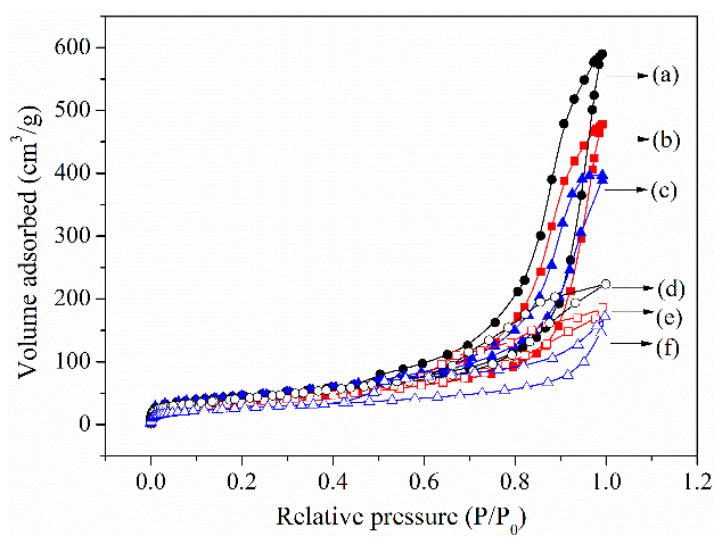

Figure 2. $\mathrm{N}_{2}$ adsorption-desorption isotherms of (a) $0.005 \mathrm{BiOCl} / \mathrm{MnMgAlO}$, (b) $0.01 \mathrm{BiOCl} / \mathrm{MnMgAlO}$, (c) $0.015 \mathrm{BiOCl} / \mathrm{MnMgAlO}$, (d) $0.005 \mathrm{BiOCl} / \mathrm{MnMgAl}-\mathrm{HT}$, (e) $0.01 \mathrm{BiOCl} / \mathrm{MnMgAl}-\mathrm{HT}$ and (f) $0.015 \mathrm{BiOCl} / \mathrm{MnMgAl}-\mathrm{HT}$. 
Table 1. Catalytic performance of samples in the removal reaction of formaldehyde ${ }^{\text {a }}$.

\begin{tabular}{|c|c|c|c|c|}
\hline Entry & Catalysts & Mn/Mg/Al Molar Ratio & $\begin{array}{l}\text { SBET } \\
\left(\mathrm{m}^{2} / \mathrm{g}\right)\end{array}$ & $\begin{array}{l}\text { Removal Efficiency } \\
\text { of Formaldehyde }{ }^{b}(\%)\end{array}$ \\
\hline 1 & blank & $-{ }^{c}$ & - & 0 \\
\hline 2 & $\mathrm{BiOCl}$ & - & 35 & 1.5 \\
\hline 3 & MnMgAl-HT & $1.45 / 1.46 / 1$ & 85 & 7.8 \\
\hline 4 & 0.015BiOCl/MnMgAl-HT & $1.46 / 1.46 / 1$ & 73 & 51.4 \\
\hline 5 & 0.012BiOCl/MnMgAl-HT & $1.45 / 1.46 / 1$ & 77 & 54.5 \\
\hline 6 & 0.01BiOCl/MnMgAl-HT & $1.45 / 1.47 / 1$ & 78 & 54.9 \\
\hline 7 & 0.005BiOCl/MnMgAl-HT & $1.47 / 1.46 / 1$ & 81 & 45.5 \\
\hline 8 & $\mathrm{MnMgAlO}$ & $1.45 / 1.45 / 1$ & 210 & 9.5 \\
\hline 9 & $0.015 \mathrm{BiOCl} / \mathrm{MnMgAlO}$ & $1.46 / 1.47 / 1$ & 197 & 80.6 \\
\hline 10 & $0.012 \mathrm{BiOCl} / \mathrm{MnMgAlO}$ & $1.45 / 1.46 / 1$ & 204 & 91.5 \\
\hline 11 & $0.01 \mathrm{BiOCl} / \mathrm{MnMgAlO}$ & $1.45 / 1.47 / 1$ & 205 & 91.0 \\
\hline 12 & $0.005 \mathrm{BiOCl} / \mathrm{MnMgAlO}$ & $1.46 / 1.45 / 1$ & 207 & 75.4 \\
\hline
\end{tabular}

a Reaction conditions: catalyst $100 \mathrm{mg}$; formaldehyde $100 \mathrm{ppm}$; air/formaldehyde $100 \mathrm{~mL} \mathrm{~min}^{-1}$; atmospheric pressure; temperature $60^{\circ} \mathrm{C}$; time $3 \mathrm{~h}$. ${ }^{\mathrm{b}}$ Removal efficiency $=$ (the outlet concentration of $\mathrm{CO}_{2}$ / the inlet concentration of formaldehyde) $\times 100 .{ }^{c}$ " - " means no detection.

TGA curves of 0.01BiMnMgAl-HT were typically illustrated in Figure 3. Three major weight losses appeared at about $55^{\circ} \mathrm{C}, 90^{\circ} \mathrm{C}$ and $290^{\circ} \mathrm{C}$, respectively. The first two peaks might be related to the removal of physically adsorbed and interlayer water, respectively. The last peak could be attributed to the dehydroxylation of layers, which led to the complete collapse of the layered structure. Moreover, no significant weight loss was found after $450{ }^{\circ} \mathrm{C}$, indicating that the mesoporous structure of mixed oxides had been formed by calcining their parent hydrotalcite-like compounds at the present calcination temperature $\left(450{ }^{\circ} \mathrm{C}\right)$. Simultaneously, it was known that $\mathrm{BiClO}$ was stable before $600^{\circ} \mathrm{C}$; thus, the above results also further confirmed that the structure of $\mathrm{BiClO}$ remained unchanged as described in XRD characterization.

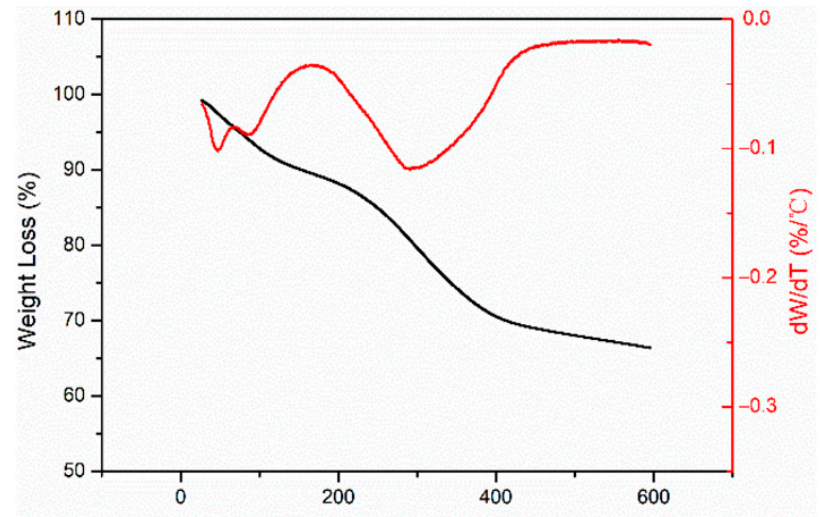

Figure 3. Thermogravimetric weight loss curve and derivative plots of $0.01 \mathrm{BiMnMgAl}-\mathrm{HT}$.

The $\mathrm{H}_{2}$-TPR images of samples are shown in Figure 4 . For the uncalcined $x \mathrm{BiOCl} / \mathrm{MnMgAl}-$ $\mathrm{HT}$, two hydrogen consumption peaks were found at about $300{ }^{\circ} \mathrm{C}$ and $450{ }^{\circ} \mathrm{C}$, which could be attributed to the redox process of $\mathrm{Mn}$. The former could be assigned to the hydrogen consumption peak of $\mathrm{Mn}^{4+}$ to $\mathrm{Mn}^{3+}$, while the latter might be due to the hydrogen consumption peak of $\mathrm{Mn}^{3+}$ to $\mathrm{Mn}^{2+}$. With regard to the peak area of the two characteristic peaks, the latter is much larger than the former. This indicated that $\mathrm{Mn}^{3+}$ and $\mathrm{Mn}^{4+}$ exist together in uncalcined $\times \mathrm{BiOCl} / \mathrm{MnMgAl}-\mathrm{HT}$, of which $\mathrm{Mn}^{3+}$ is the dominant state. In contrast, for the calcined $\times \mathrm{BiOCl} / \mathrm{MnMgAlO}$, only one hydrogen consumption peak appeared at about $410{ }^{\circ} \mathrm{C}$, suggesting the presence of single $\mathrm{Mn}^{3+}$ due to the redox of $\mathrm{Mn}^{4+}$ to $\mathrm{Mn}^{3+}$ during calcination. Moreover, $\mathrm{xBiOCl} / \mathrm{MnMgAlO}$ showed a lower reduction temperature of $\mathrm{Mn}^{3+}$ than $\times \mathrm{BiOCl} / \mathrm{MnMgAl}-\mathrm{HT}$. It was accepted that the shifts of hydrogen consumption peaks to lower temperatures were ascribed to the formation of more active 
oxygen species [28,36]. It could be deduced that the relatively large number of surface oxygen species in $\mathrm{xBiOCl} / \mathrm{MnMgAlO}$ could be produced by their more surface oxygen vacancies, which were generated to maintain the electrostatic balance due to the presence of the more reduced element state of $\mathrm{Mn}^{3+}$. This also suggested that $\mathrm{xBOCl} / \mathrm{MnMgAlO}$ would show increased redox capacity in comparison with $\mathrm{xBiOCl} / \mathrm{MnMgAl}-\mathrm{HT}$.

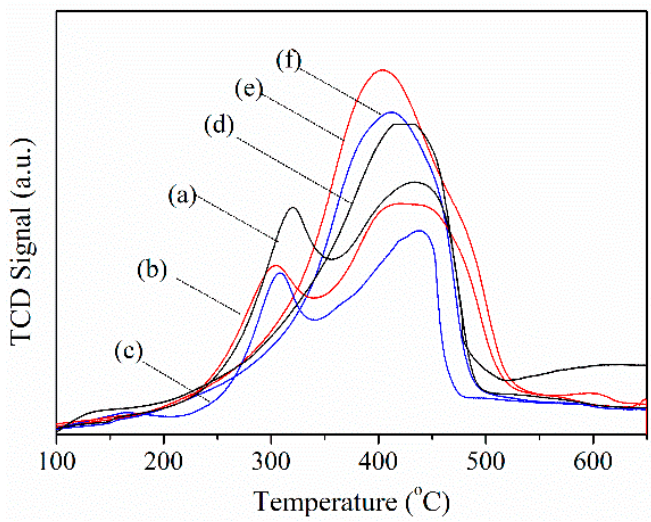

Figure 4. $\mathrm{H}_{2}$-TPR images of (a) $0.005 \mathrm{BiOCl} / \mathrm{MnMgAlO}$, (b) $0.01 \mathrm{BiOCl} / \mathrm{MnMgAlO}$, (c) 0.015BiOCl/MnMgAlO, (d) $0.005 \mathrm{BiOCl} / \mathrm{MnMgAl}-\mathrm{HT}$, (e) $0.01 \mathrm{BiOCl} / \mathrm{MnMgAl}-\mathrm{HT}$ and (f) 0.015BiOCl/MnMgAl-HT.

The $\mathrm{O}_{2}$-TPD profiles of $0.005 \mathrm{BiOCl} / \mathrm{MnMgAlO}, 0.01 \mathrm{BiOCl} / \mathrm{Mn} \mathrm{MgAlO}$ and $0.015 \mathrm{BiO}$ $\mathrm{Cl} / \mathrm{MnMgAlO}$ are depicted in Figure 5. Generally, three oxygen desorption peaks were detected, including low temperature $\left(378{ }^{\circ} \mathrm{C}\right)$, medium temperature $\left(500 \sim 550{ }^{\circ} \mathrm{C}\right)$ and high temperature $\left(>600^{\circ} \mathrm{C}\right)$, which could be ascribed to the surface active oxygen $\left(\mathrm{O}_{2}^{-}\right.$and $\left.\mathrm{O}^{-}\right)$, the surface lattice oxygen $\left(\mathrm{O}^{2-}\right)$ and the bulk lattice oxygen, respectively $[20,21,29]$. Moreover, with the rise in $\mathrm{BiOCl}$ loading, the low-temperature desorption peaks in three catalysts enhanced first and then weakened, indicating that the amount of active oxygen species increased first and then decreased. However, no significant shifts were found in the position of their low-temperature desorption peaks, suggesting that the relative number of surface active oxygen species did not change with the increased BiOCl loading. For the medium desorption peaks of the three supported catalysts, no significant differences were detected in the desorption peak intensities of $0.005 \mathrm{BiOCl} / \mathrm{MnMgAlO}$ and $0.01 \mathrm{BiOCl} / \mathrm{MnMgAlO}$, while the peak position shifted to lower temperature with the increasing of BiOCl loading. This indicated that the surface lattice oxygen in the catalyst with high BiOCl loading was more active; however, the increased $\mathrm{BiOCl}$ loading did not influence the amount of surface lattice oxygen. With respect to $0.015 \mathrm{BiOCl} / \mathrm{MnMgAlO}$, compared to $0.01 \mathrm{BiOCl} / \mathrm{MnMgAlO}$, the peak intensities associated with low temperature and medium temperature desorption weakened, revealing that the amount of surface active oxygen and lattice oxygen both decreased, which might be attributed to the excessive loading of BiOCl. Noticeably, the desorption peak related to bulk lattice oxygen appeared in $0.015 \mathrm{BiOCl} / \mathrm{MnMgAlO}$, which might be generated to compensate for the decreased surface active oxygen and lattice oxygen originated from the introduction of excessive $\mathrm{BiOCl}$.

The surface basicity of the obtained three mixed-oxide-supported catalysts was further investigated, and their $\mathrm{CO}_{2}$-TPD profiles are shown in Figure 6 . Three $\mathrm{CO}_{2}$ desorption peaks were detected, which could be assigned to the weak basic sites (around $100{ }^{\circ} \mathrm{C}$ ), moderate basic sites (around $235^{\circ} \mathrm{C}$ ) and strong basic sites $\left(>390^{\circ} \mathrm{C}\right)[37,38]$. The weak basic sites could be ascribed to the abundant surface $\mathrm{OH}^{-}$groups, the moderate basic sites might be related to $\mathrm{Mg}-\mathrm{O}$ and $\mathrm{Al}-\mathrm{O}$ pairs and the strong basic sites might be associated with coordinatively unsaturated lattice oxygen $\left(\mathrm{O}^{2-}\right)$ [39-41]. Furthermore, Figure 6 also illustrated that the characteristic peaks of weak basic sites and strong basic sites in $0.01 \mathrm{BiOCl} / \mathrm{MnMgAlO}$ both shifted to high temperatures in comparison with those in $0.005 \mathrm{BiOCl} / \mathrm{MnMgAlO}$. A much higher $\mathrm{CO}_{2}$ uptake was also found in $0.01 \mathrm{BiOCl} / \mathrm{MnMgAlO}$ than in $0.005 \mathrm{BiOCl} / \mathrm{MnMgAlO}$ (see Table 2). This indicated that 
the basicity of weak and strong basic sites increased with the rise in BiOCl loading. The increased basicity of weak basic sites could be attributed to the more surface $\mathrm{OH}^{-}$groups in the catalyst with higher BiOCl loading than in the catalyst with lower BiOCl loading. The increased basicity of strong basic sites might be caused by the effect of the increased $\mathrm{BiOCl}$ loading on the mixed oxide support. However, with the further increase in the loading of $\mathrm{BiOCl}$, slight shifts in the characteristic peaks ascribed to the weak and strong basic sites to low temperatures were found in the $\mathrm{CO}_{2}-\mathrm{TPD}$ profiles of $0.015 \mathrm{BiOCl} / \mathrm{MnMgAlO}$. Simultaneously, a relatively decreased $\mathrm{CO}_{2}$ uptake was also detected (see Table 2). The presence of a small amount of $\mathrm{Bi}_{2} \mathrm{O}_{3}$ in $0.015 \mathrm{BiOCl} / \mathrm{MnMgAlO}$, as confirmed by XRD characterization due to the excessive loading, might afford the above-mentioned slight decreased surface basicity.

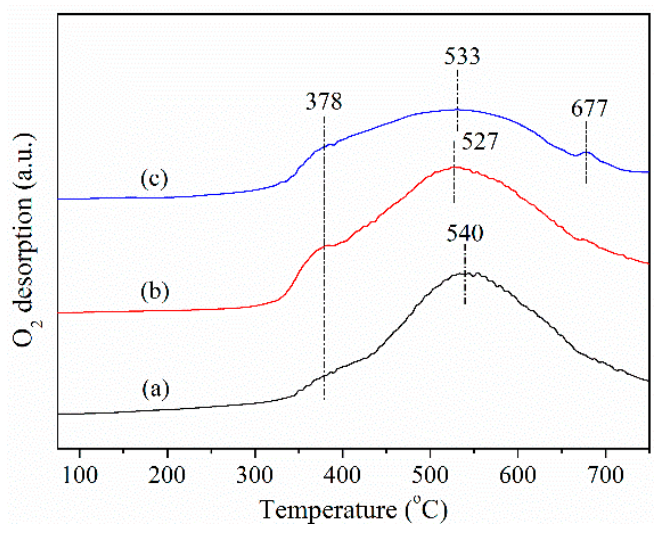

Figure 5. $\mathrm{O}_{2}$-TPD images of (a) $0.005 \mathrm{BiOCl} / \mathrm{MnMgAlO}$, (b) $0.01 \mathrm{BiOCl} / \mathrm{MnMgAlO}$ and (c) $0.015 \mathrm{BiOCl} / \mathrm{MnMgAlO}$.

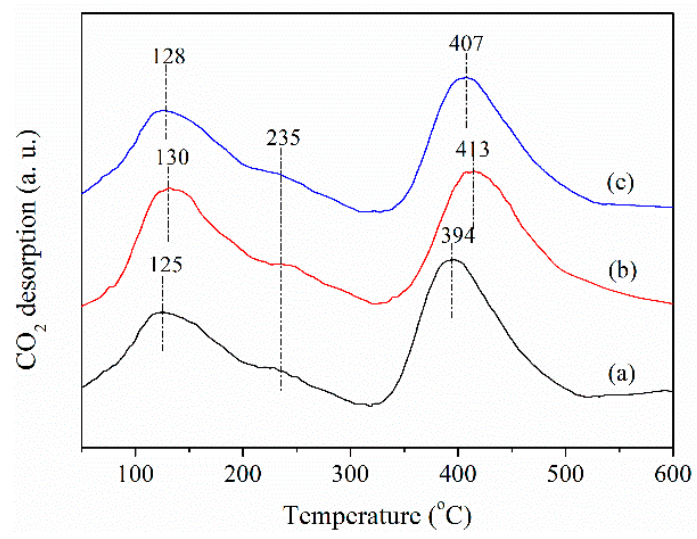

Figure 6. $\mathrm{CO}_{2}$-TPD images of (a) $0.005 \mathrm{BiOCl} / \mathrm{MnMgAlO}$, (b) $0.01 \mathrm{BiOCl} / \mathrm{MnMgAlO}$ and (c) 0.015BiOCl/MnMgAlO.

Table 2. Basicity of different catalysts.

\begin{tabular}{lccc}
\hline \multirow{2}{*}{ Sample } & \multicolumn{3}{c}{$\mathrm{CO}_{\mathbf{2}}$ Uptake $(\mu \mathbf{m o l} / \mathbf{g}){ }^{\mathbf{a}}$} \\
\cline { 2 - 4 } & Weak Basic Sites & Moderate Basic Sites & Strong Basic Sites \\
\hline $0.005 \mathrm{BiOCl} / \mathrm{MnMgAlO}$ & 32.5 & 6.7 & 45.3 \\
$0.01 \mathrm{BiOCl} / \mathrm{MnMgAlO}$ & 37.8 & 9.5 & 53.2 \\
$0.015 \mathrm{BiOCl} / \mathrm{MnMgAlO}$ & 34.6 & 8.6 & 48.6 \\
\hline
\end{tabular}

${ }^{a}$ Relative amounts of the basic sites (\%) calculated from the peak area.

XPS was performed to investigate the surface chemical state of catalysts. XPS spectra of $\mathrm{Bi} 4 \mathrm{f}$ of pure commercial $\mathrm{BiOCl}, 0.01 \mathrm{BiOCl} / \mathrm{MnMgAl}-\mathrm{HT}$ and $0.01 \mathrm{BiOCl} / \mathrm{MnMgAlO}$ were typically illustrated in Figure 7A. It was found that two characteristic peaks at about 
$164.5 \mathrm{eV}$ and $159.2 \mathrm{eV}$ corresponding to $\mathrm{Bi}^{3+}$ appeared in the XPS spectra of pure BiOCl. In contrast, in the spectra of $0.01 \mathrm{BiOCl} / \mathrm{MnMgAl}-\mathrm{HT}$ and $0.01 \mathrm{BiOCl} / \mathrm{MnMgAlO}$, those two peaks showed small shifts to low binding energies, indicating the presence of the $+(3-x)$ oxidation state of Bi. This could be attributed to the formation of more oxygen vacancies on the surface of $\mathrm{BiOCl}$ in the supported catalysts in comparison with those on the surface of commercial $\mathrm{BiOCl}$, which originated from the interaction of $\mathrm{BiClO}$ and supports during loading $[31,32]$. In view of the two supported catalysts, no significant differences were found in their XPS spectra, suggesting the almost identical surface chemical states of Bi in $0.01 \mathrm{BiOCl} / \mathrm{MnMgAl}-\mathrm{HT}$ and $0.01 \mathrm{BiOCl} / \mathrm{MnMgAlO}$.

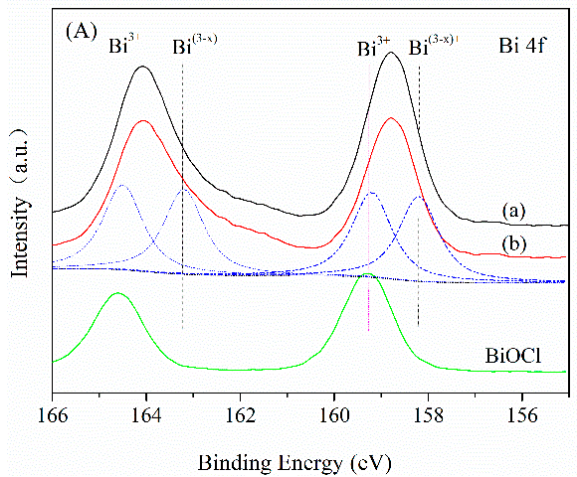

Figure 7. XPS spectra of (A) $\mathrm{Bi} 4 \mathrm{f}$ and (b) $0.01 \mathrm{BiOCl} / \mathrm{MnMgAlO}$.

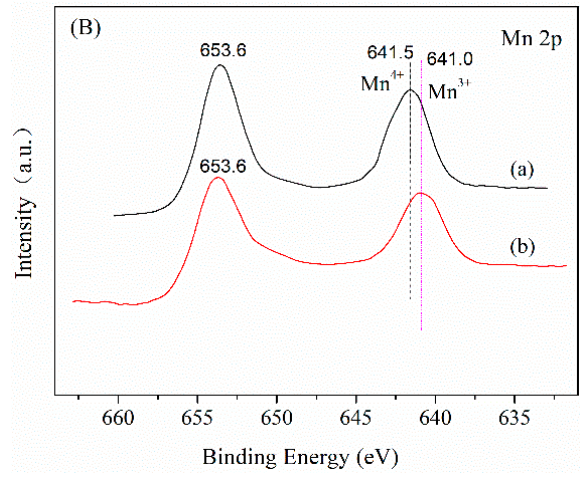

(B) $\mathrm{Mn} \mathrm{2p}$, (a) $0.01 \mathrm{BiOCl} / \mathrm{MnMgAl}-\mathrm{HT}$ and

XPS spectra of Mn $2 \mathrm{p}$ of $0.01 \mathrm{BiOCl} / \mathrm{MnMgAl}-\mathrm{HT}$ and $0.01 \mathrm{BiOCl} / \mathrm{MnMgAlO}$ were typically illustrated in Figure 7B. In the XPS spectra of $0.01 \mathrm{BiOCl} / \mathrm{MnMgAl}-\mathrm{HT}$, two peaks at $641.5 \mathrm{eV}$ and $653.6 \mathrm{eV}$ could be attributed to $\mathrm{Mn} 2 \mathrm{p} 2 / 3$ and $\mathrm{Mn} 2 \mathrm{p} 1 / 2$. By the curve fitting analysis of Mn 2p2/3, Mn3+ was found to be the predominant oxidation state in $0.01 \mathrm{BiOCl} / \mathrm{MnMgAl}-\mathrm{HT}$. When it comes to the XPS spectra of $0.01 \mathrm{BiOCl} / \mathrm{MnMgAlO}$, the peak assigned to $\mathrm{Mn} 2 \mathrm{p} 2 / 3$ shifted to $641.0 \mathrm{eV}$, indicating the absence of $\mathrm{Mn} 4+$ due to the redox of $\mathrm{Mn}^{4+}$ to $\mathrm{Mn}^{3+}$ during calcination. This fit well with the results of $\mathrm{H}_{2}$-TPR and further demonstrated the different chemical states of $\mathrm{Mn}$ in the two supported catalysts.

SEM images of $0.01 \mathrm{BiOCl} / \mathrm{MnMgAl}-\mathrm{HT}$ and $0.01 \mathrm{BiOCl} / \mathrm{MnMgAlO}$ are typically displayed in Figure 8A,B. 0.01BiOCl/MnMgAl-HT showed lamella structure with lateral sizes of platelets about $50 \sim 150 \mathrm{~nm}$, indicating that the layered morphology of hydrotalcite-like compounds and $\mathrm{BiOCl}$ was not altered during loading. After calcination, two spherical or ellipsoidal particles with an average diameter of 300-400 and 20-100 nm were found in the SEM image of $0.01 \mathrm{BiOCl} / \mathrm{MnMgAlO}$, which could be assigned to mixed oxide support and $\mathrm{BiOCl}$, respectively.
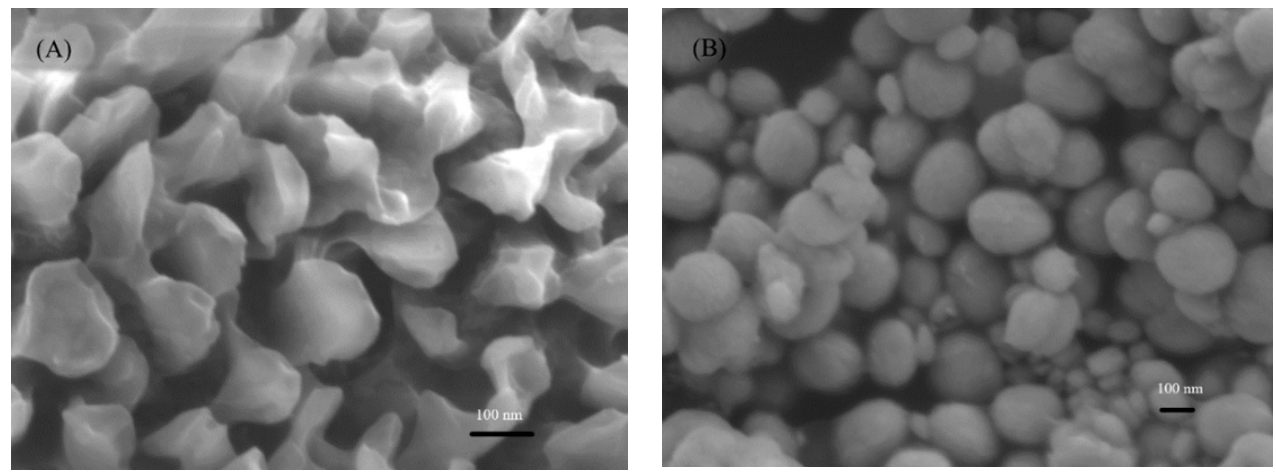

Figure 8. SEM images of (A) $0.01 \mathrm{BiOCl} / \mathrm{MnMgAl}-\mathrm{HT}$ and (B) $0.01 \mathrm{BiOCl} / \mathrm{MnMgAlO}$. 


\subsection{Catalytic Performance and Stability of Catalysts}

In the present work, the obtained $\times \mathrm{BiOCl} / \mathrm{MnMgAl}-\mathrm{HT}$ and $\times \mathrm{BiOCl} / \mathrm{MnMgAlO}$ catalysts were used in the oxidation removal of formaldehyde (see Table 1). The results revealed that pure $\mathrm{BiOCl}$ hardly showed effective formaldehyde removal efficiency (Entry 2). Though $\mathrm{BiOCl}$ has widely been accepted as a good photocatalyst for oxidation removal of pollutants, under the current $\mathrm{UV}$-free reaction conditions, $\mathrm{BiOCl}$ itself did not seem to be active in the oxidation removal of formaldehyde. Similarly, the catalytic performance of the pure $\mathrm{MnMgAl}-\mathrm{HT}$ or $\mathrm{MnMgAlO}$ was also poor, and the formaldehyde removal

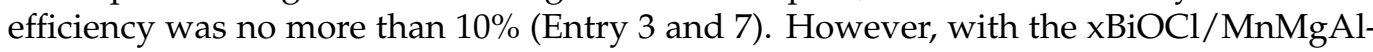
$\mathrm{HT}$ or $\mathrm{xBiOCl} / \mathrm{MnMgAlO}$ used as catalyst, dramatically enhanced formaldehyde removal efficiency was found (Entry 4-6 and 8-10). Such an increased catalytic performance could be related to the generation of more oxygen vacancies on the surface of $\mathrm{BiOCl}$ in the supported catalysts than in the pure $\mathrm{BiOCl}$, which caused more surface active oxygen species and thus facilitated the oxidation removal reaction. This also suggested that certain synergetic catalysis was present between $\mathrm{BiOCl}$ and the supports of $\mathrm{MnMgAl}-\mathrm{HT}$ or $\mathrm{MnMgAlO}$.

With regard to the catalytic performance of the supported $\mathrm{BiOCl}$ materials before and after calcination, $\mathrm{xBiOCl} / \mathrm{MnMgAlO}$ showed much higher catalytic performance than $\mathrm{xBiOCl} / \mathrm{MnMgAl}-\mathrm{HT}$. It was known that the supports of heterogeneous catalysts influenced mainly their catalytic performance by regulating the adsorption capacity to reactants. The dried formaldehyde itself is not ionized and thus is neutral. However, as the oxidation progressed, the metabolite water that appeared in the reaction system induced forming the dimeric of formaldehyde with weak acidity. For the supported catalysts, the surface basicity of mixed-oxide-supported $\mathrm{BiOCl}$ compounds was much higher than that of hydrotalcite-supported catalysts because the inherent basic sites of hydrotalcite-like compounds were fully explored during calcination. Therefore, more formaldehyde molecules could be adsorbed on the surface of mixed-oxide-supported catalysts, which had been verified by the following in situ FTIR experiments (see Figure 11). This increased the probability of formaldehyde molecules being further oxidized and could afford the high catalytic performance of $\mathrm{xBiOCl} / \mathrm{MnMgAlO}$ to a certain degree. At the same time, $\mathrm{H}_{2}$-TPR and XPS spectra of Mn 2p illustrated that the presence of more $\mathrm{Mn}^{3+}$ in $\mathrm{xBiOCl} / \mathrm{MnMgAlO}$ also induced more oxygen vacancies on their support surface, which led to more surface active oxygen species and higher redox capacity in $\times \mathrm{BiOCl} / \mathrm{MnMgAlO}$ than that in $\mathrm{xBiOCl} / \mathrm{MnMgAl}-\mathrm{HT}$. This might also contribute to the higher catalytic performance of $\mathrm{xBiOCl} / \mathrm{MnMgAlO}$.

Furthermore, the loading of $\mathrm{BiOCl}$ was also found to significantly influence the catalytic performance of supported catalysts. The hydrotalcite- and mixed-oxide-supported catalysts both exhibited an enhanced formaldehyde removal efficiency first with the increased loading of $\mathrm{BiOCl}$ to $0.01 \%$, which could be attributed to the demand for enough catalytic active sites for the oxidation removal reaction. However, with the further increase in the loading of $\mathrm{BiOCl}$, the formaldehyde removal efficiency then decreased. Such a decreased removal efficiency could be related to the decreased surface area and surface basicity of catalysts. In addition, for $0.015 \mathrm{BiOCl} / \mathrm{MnMgAlO}$, the presence of a small minority of $\mathrm{Bi}_{2} \mathrm{O}_{3}$ secondary phases with weak acidity could cause a decreased adsorption capacity of catalysts for formaldehyde, which could also afford the decrease in the formaldehyde removal efficiency.

The effect of the reaction time and temperature on the catalytic performance of six supported $\mathrm{BiOCl}$ catalysts was also investigated in detail (see Figure 9). Generally speaking, $\mathrm{xBiOCl} / \mathrm{MnMgAlO}$ displayed significantly high catalytic performance in the formaldehyde removal reaction in comparison with $\mathrm{xBiOCl} / \mathrm{MnMgAl}-\mathrm{HT}$. Under a sufficient reaction time and temperature, the formaldehyde removal efficiency could reach $100 \%$ over $\mathrm{xBiOCl} / \mathrm{MnMgAlO}$, while about $70 \%$ of formaldehyde removal efficiency was achieved over $\times \mathrm{BiOCl} / \mathrm{MnMgAl}-\mathrm{HT}$. Such a difference could be attributed to the different surface properties and chemical state of $\mathrm{Mn}$ in the two supported catalysts, which was discussed above. However, the performance trends of the two catalysts were found to be almost 
identical with the rise in reaction time and temperature. A sharp increase in the formaldehyde removal efficiency appeared with the increased reaction time and temperature, which might be related to the increased probability of adsorption and surface reactivity of reactant molecules at high temperatures and long times. In the presence of $x \mathrm{BiOCl} / \mathrm{MnMgAl}-\mathrm{HT}$, the optimal reaction time and temperature were $240 \mathrm{~min}$ and $90{ }^{\circ} \mathrm{C}$, respectively. In contrast, with $\times \mathrm{BiOCl} / \mathrm{MnMgAlO}$ as a catalyst, the complete formaldehyde removal efficiency could be achieved when the reaction was performed at $70^{\circ} \mathrm{C}$ and $220 \mathrm{~min}$, respectively. Such reaction results were rarely achieved over low-priced metal catalysts at such a low temperature and short time, so the $\mathrm{Mn}$-containing mixed-oxides-supported $\mathrm{BiOCl}$ catalyst showed potential application value.
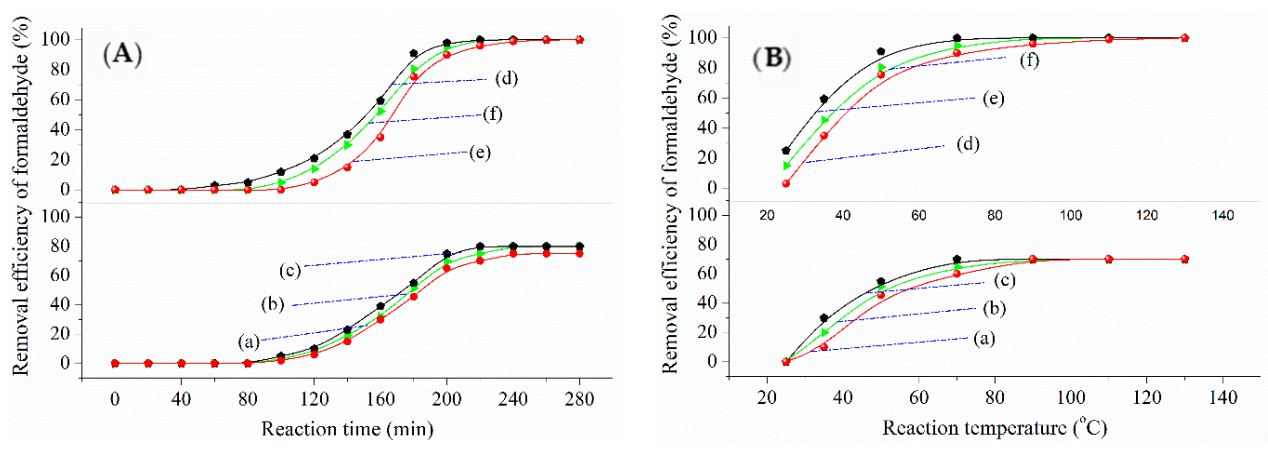

Figure 9. Effect of reaction time $(\mathbf{A})$ and temperature $(\mathbf{B})$ on the catalytic performance of catalysts. (a) $0.005 \mathrm{BiOCl} / \mathrm{MnMgAl}-\mathrm{HT}$, (b) 0.01BiOCl/MnMgAl-HT, (c) 0.015BiOCl/MnMgAl-HT, (d) $0.005 \mathrm{BiOCl} / \mathrm{MnMgAlO}$, (e) $0.01 \mathrm{BiOCl} / \mathrm{MnMgAlO}$ and (f) $0.015 \mathrm{BiOCl} / \mathrm{MnMgAlO}$.

Reaction conditions: Left part, catalyst $100 \mathrm{mg}$, formaldehyde $100 \mathrm{ppm}$, air/formaldehyde $100 \mathrm{~mL} \mathrm{~min}{ }^{-1}$, atmospheric pressure; temperature $60^{\circ} \mathrm{C}$; Right part, catalyst $100 \mathrm{mg}$, formaldehyde $100 \mathrm{ppm}$, air/formaldehyde $100 \mathrm{~mL} \mathrm{~min}^{-1}$, atmospheric pressure, time $3 \mathrm{~h}$.

$0.01 \mathrm{BiOCl} / \mathrm{MnMgAlO}$, which exhibited the best catalytic performance in the oxidation removal of formaldehyde, was selected as the representative catalyst to carry out the stability test at $70{ }^{\circ} \mathrm{C}$. The results in Figure 10 illustrated that the formaldehyde removal efficiency was maintained at more than $90 \%$ for $21 \mathrm{~h}$. The slight decrease in catalytic performance could be attributed to the accumulation of a little carbonates on the surface of catalysts. This indicated that the $\mathrm{Mn}$-containing mixed-oxide-supported $\mathrm{BiOCl}$ catalyst was stable in the present oxidation removal conditions.

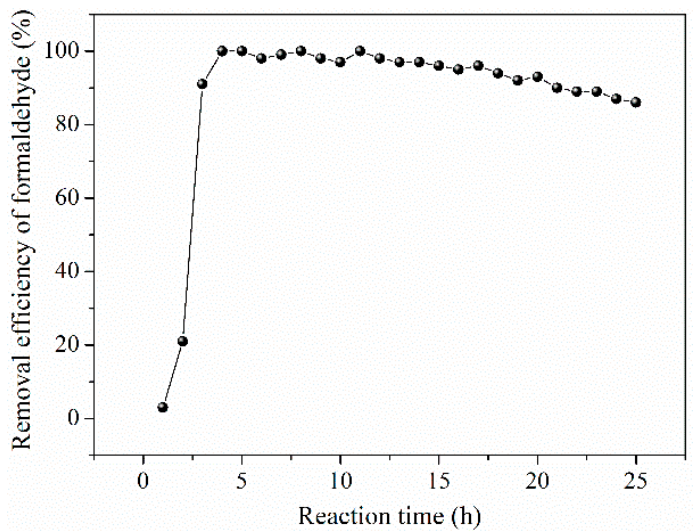

Figure 10. Stability of the representative catalyst $0.01 \mathrm{BiOCl} / \mathrm{MnMgAlO}$.

Reaction conditions: catalyst $100 \mathrm{mg}$, formaldehyde $100 \mathrm{ppm}$, air/formaldehyde $100 \mathrm{~mL} \mathrm{~min}^{-1}$, atmospheric pressure; temperature $70^{\circ} \mathrm{C}$. 


\subsection{Structure Activity Relationship of Catalysts and Possible Reaction Mechanism}

In situ ATR-IR spectra of $0.01 \mathrm{BiOCl} / \mathrm{MnMgAlO}$ and $0.01 \mathrm{BiOCl} / \mathrm{MnMgAl}-\mathrm{HT}$ are typically illustrated in Figure 11 . When the $0.01 \mathrm{BiOCl} / \mathrm{MnMgAlO}$ sample was exposed to $\mathrm{HCHO}$ in air, the characteristic peaks of polyformaldehyde $\left(929 \mathrm{~cm}^{-1}\right)$, dioxymethylene $\left(1091 \mathrm{~cm}^{-1}\right)$, carbonate $\left(1238\right.$ and $\left.1280 \mathrm{~cm}^{-1}\right)$, formate $\left(1340\right.$ and $\left.1560 \mathrm{~cm}^{-1}\right)$, bicarbonate (1430 and $\left.1603 \mathrm{~cm}^{-1}\right)$, water $\left(1645 \mathrm{~cm}^{-1}\right)$ and $\mathrm{CO}_{2}\left(2341 \mathrm{~cm}^{-1}\right)$ were observed [42,43] (see Figure 11A). Moreover, all the above peaks of intermediate or product species enhanced with the increasing exposure time from 10 to $30 \mathrm{~min}$, indicating that more $\mathrm{HCHO}$ molecules were oxidized. However, with the further extension of the reaction time to $40 \mathrm{~min}$, the characteristic peaks corresponding to polyformaldehyde, dioxymethylene, carbonate, formate and bicarbonate species weakened, and simultaneously, the $\mathrm{CO}_{2}$ characteristic peak enhanced significantly. This suggested that more intermediate species were further oxidized into $\mathrm{CO}_{2}$ with the prolonging of the reaction time.
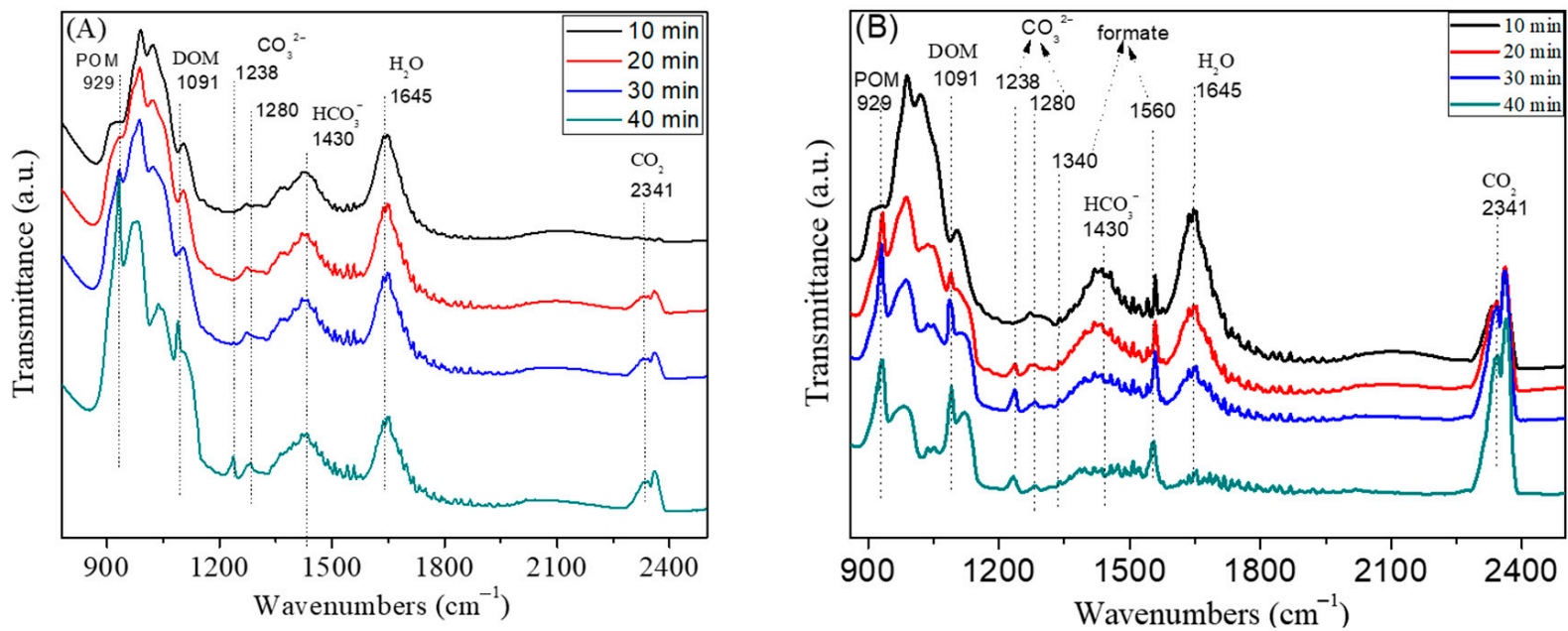

Figure 11. FTIR spectra of (A) $0.01 \mathrm{BiOCl} / \mathrm{MnMgAl}-\mathrm{HT}$ and (B) $0.01 \mathrm{BiOCl} / \mathrm{MnMgAlO}$.

In the case of the $0.01 \mathrm{BiOCl} / \mathrm{MnMgAl}-\mathrm{HT}$, upon being exposed to $\mathrm{HCHO}$ and air, the intensity of the characteristic peaks ascribed to polyformaldehyde $\left(929 \mathrm{~cm}^{-1}\right)$ and dioxymethylene $\left(1091 \mathrm{~cm}^{-1}\right)$ increased continuously when the reaction time increased from 10 to $40 \mathrm{~min}$ (see Figure 11B). Moreover, no peaks ascribed to formate species were detected, and the enhancement of the $\mathrm{CO}_{2}$ characteristic peak was not obvious compared to the peak in the spectra of $0.01 \mathrm{BiOCl} / \mathrm{MnMgAlO}$. This indicated that the intermediate product of polyformaldehyde and dioxymethylene were not oxidized effectively into formate and $\mathrm{CO}_{2}$ over $0.01 \mathrm{BiOCl} / \mathrm{MnMgAl}-\mathrm{HT}$, probably because of its relatively few surface oxygen vacancies and basicity. This also suggested that the conversion of polyformaldehyde and dioxymethylene into formate might be the rate-determining step for $\mathrm{HCHO}$ oxidation in the present catalytic systems. Furthermore, the following possible reaction mechanism was also proposed (see Scheme 1). According to the Mars-Van-Krevelen oxidation-reduction mechanism, $\mathrm{O}_{2}$ and lattice oxygen $\mathrm{O}^{2-}$ can be transformed into each other. Thus, $\mathrm{O}_{2}$ was firstly transformed into $\mathrm{O}^{2-}$. Then, $\mathrm{O}^{2-}$ could be oxidized to $\mathrm{O}_{2}{ }^{-}$with a stronger oxidation capacity on the oxygen vacancies of the catalyst. Simultaneously, formaldehyde could be adsorbed by the basic surface -OH groups. The adsorbed formaldehyde molecules in the form of polyformaldehyde were oxidized into dioxymethylene, and then reacted with the active oxygen species $\mathrm{O}_{2}{ }^{-}$to produce formate and carbonate (rate-determining step). Subsequently, the formate and carbonate would further react with active oxygen species to obtain $\mathrm{CO}_{2}$ and $\mathrm{H}_{2} \mathrm{O}$. 


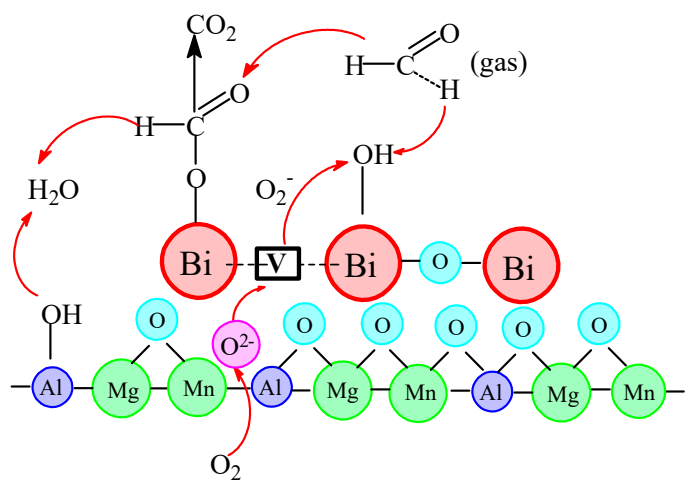

Scheme 1. Possible mechanism of the oxidation removal of formaldehyde over $0.01 \mathrm{BiOCl} / \mathrm{MnMgAlO}$.

\section{Experimental}

\subsection{Catalyst Preparation}

Typically, $0.04 \mathrm{~mol}$ of $\mathrm{Mn}\left(\mathrm{NO}_{3}\right)_{2} \cdot 6 \mathrm{H}_{2} \mathrm{O}, 0.04 \mathrm{~mol}$ of $\mathrm{Mg}\left(\mathrm{NO}_{3}\right)_{2} \cdot 6 \mathrm{H}_{2} \mathrm{O}$ and $0.04 \mathrm{~mol}$ of $\mathrm{Al}\left(\mathrm{NO}_{3}\right)_{3} \cdot 9 \mathrm{H}_{2} \mathrm{O}$ were added concurrently to $120 \mathrm{~mL}$ of deionized water under vigorous stirring at room temperature to prepare the aqueous solution $\mathrm{A} . \mathrm{x}$ mol of $\mathrm{BiCl}_{3}(\mathrm{x}=0.005$, $0.01,0.012$ and $0.015 \mathrm{~mol}$ ) was added to $60 \mathrm{~mL}$ absolute alcohol under vigorous stirring at room temperature to prepare the alcohol solution $B$. Then, $0.06 \mathrm{~mol} \mathrm{Na}_{2} \mathrm{CO}_{3}$ was added to $120 \mathrm{~mL}$ of deionized water with stirring to prepare the aqueous solution $\mathrm{C}$. Then, solution $\mathrm{A}$ and $\mathrm{B}$ were simultaneously added dropwise to solution $\mathrm{C}$ with stirring at $80{ }^{\circ} \mathrm{C}$ for 1.0 1.5 $\mathrm{h}$. In the process of dropping, the appropriate amount of $\mathrm{NaOH}$ was added into the mixture to maintain its $\mathrm{pH}$ value at $10.0 \pm 0.5$. The resulting gel-like slurry was further aged with stirring for $12 \mathrm{~h}$ at room temperature, and then was filtered and washed with deionized water until $\mathrm{pH}=7$. The filtrate was dried in air at $373 \mathrm{~K}$ for $12 \mathrm{~h}$, and the obtained solid samples were designated as $\mathrm{xBiOCl} / \mathrm{MnMgAl}-\mathrm{HT}$.

$\mathrm{XBiOCl} / \mathrm{MnMgAl}-\mathrm{HT}$ was further calcined at $450{ }^{\circ} \mathrm{C}$ under $\mathrm{N}_{2}$ for $8 \mathrm{~h}$, and the as-prepared solid samples were designated as $\mathrm{xBiOCl} / \mathrm{MnMgAlO}(\mathrm{x}=0.005,0.01$ and $0.015 \mathrm{~mol})$.

\subsection{Characterization}

The elemental composition of samples was detected using the inductively coupled plasma-optical (ICP) emission spectroscopy (PerkinElmer ICP OPTIMA-3000). Powder Xray diffraction $(\mathrm{XRD})$ experiments were run on a Rigaku Miniflex diffractometer with a $\mathrm{Ni}$ filter using a $\mathrm{Cu}$ target. The X-ray gun operated at $30 \mathrm{~mA}$ and $50 \mathrm{kV}$ with a scan speed rate of $0.2^{\circ} / \mathrm{min} . \mathrm{N}_{2}$ adsorption-desorption isotherms of samples were measured using static adsorption procedures at $77 \mathrm{~K}$ on a Micromeritics ASAP-2000 instrument (Norcross, GA), and the surface areas of samples were obtained using the BET method. Thermogravimetric analysis (TGA) was performed on a Setaram TGA-92 thermal analyzer under nitrogen, and the samples were heated from 50 to $700{ }^{\circ} \mathrm{C}$ at $10^{\circ} \mathrm{C} / \mathrm{min}$. X-ray photoelectron spectra (XPS) of samples were obtained using Perkin-Elmer PHI 5000C, and all binding energies were calibrated according to the reference of contaminant carbon $(\mathrm{C} 1 \mathrm{~S}=284.6 \mathrm{eV})$. Scan electron microscope (SEM) experiments were performed on the JEOL JSM-7600F microscope.

The temperature-programmed reduction $\left(\mathrm{H}_{2}\right.$-TPR) equipment (Finesorb-3010) consisted of a thermal conductivity detector (TCD) connected to a flow-control system and a programmed heating unit. In each test, $0.1 \mathrm{~g}$ of the sample (40-60 mesh) was placed in a quartz reactor and reduced in $10 \% \mathrm{H}_{2}$ in $\mathrm{N}_{2}$ at a flow rate of $60 \mathrm{~mL} \mathrm{~min}{ }^{-1}$ with a heating rate of $10{ }^{\circ} \mathrm{C} \mathrm{min}^{-1}$ from $50{ }^{\circ} \mathrm{C}$ to $700{ }^{\circ} \mathrm{C}$.

$\mathrm{CO}_{2}$ temperature-programmed desorption $\left(\mathrm{CO}_{2}-\mathrm{TPD}\right)$ and $\mathrm{O}_{2}$ temperature-programmed desorption $\left(\mathrm{O}_{2}\right.$-TPD) tests were performed on the same instrument as $\mathrm{H}_{2}$-TPR. Prior to each test, $0.1 \mathrm{~g}$ of the sample (40-60 mesh) was pre-treated in a Ar flow $\left(60 \mathrm{~mL} \mathrm{~min}^{-1}\right)$ at $300{ }^{\circ} \mathrm{C}$ for $30 \mathrm{~min}$ with a heating rate of $10^{\circ} \mathrm{C} \mathrm{min}-1$, followed by cooling down to $50{ }^{\circ} \mathrm{C}$ in the same flow in order to yield clean surfaces. Afterward, a flow of $\mathrm{CO}_{2}$ or $21 \% \mathrm{O}_{2} / \mathrm{N}_{2}$ at 
a rate of $20 \mathrm{~mL} \mathrm{~min}{ }^{-1}$ was passed through the sample for $1 \mathrm{~h}$ at $50{ }^{\circ} \mathrm{C}$. Additionally, the physically adsorbed $\mathrm{CO}_{2}$ or $\mathrm{O}_{2}$ was purged off for $1 \mathrm{~h}$. Finally, the sample was heated from $50{ }^{\circ} \mathrm{C}$ to $700{ }^{\circ} \mathrm{C}$ at a rate of $10{ }^{\circ} \mathrm{C} \mathrm{min}-1$ for the desorption of the previous adsorbed $\mathrm{CO}_{2}$ or $\mathrm{O}_{2}$ in a flow of $\mathrm{Ar}\left(60 \mathrm{~mL} \mathrm{~min}^{-1}\right)$.

In situ ATR-IR experiments were studied on a Fourier transform infrared spectroscopy (Bruker Tensor-27) from 400 to $4000 \mathrm{~cm}^{-1}$ equipped with an attenuated total reflection (ATR) accessory. Considering the low concentration of formaldehyde in our test, formaldehyde droplets $(37 \mathrm{w} . \%)$ were dropped to the catalysts powder. The samples were exposed to air and identified at different times (10, 20, 30, $40 \mathrm{~min})$.

\subsection{Oxidation Removal Reaction of Formaldehyde}

Typically, $100 \mathrm{mg}$ catalyst was loaded in an affixed-bed quartz tube reactor (diameter $=4 \mathrm{~mm}$ ). Under atmospheric pressure, a gas reactant mixture of $100 \mathrm{ppm}$ formaldehyde and air was passed through the catalyst bed at $100 \mathrm{~mL} \mathrm{~min}^{-1}$. The gaseous formaldehyde was produced by passing air flow over the formaldehyde solution at $0{ }^{\circ} \mathrm{C}$. Outflow gases were analyzed using an online Agilent 8600 gas chromatograph equipped with an FID detector. The removal efficiency of formaldehyde was evaluated in terms of $\mathrm{CO}_{2}$ concentration according to the carbon balance.

\section{Conclusions}

$\mathrm{xBiOCl} / \mathrm{MnMgAlO}$ was a promising catalyst in the low-temperature oxidation removal of formaldehyde in air. The complete removal efficiency of formaldehyde could be achieved at $70{ }^{\circ} \mathrm{C}$ when the reaction was performed for $200 \mathrm{~min}$. Such a high catalytic performance could be attributed to the synergetic catalysis of abundant surface oxygen vacancies and high surface basicity. The surface oxygen vacancies derived from the presence of the reduced element state of $\mathrm{Bi}^{(3-x)+}$ on the surface of $\mathrm{BiOCl}$ and $\mathrm{Mn}^{3+}$ on the surface of $\mathrm{MnMgAlO}$ support, which induced the generation of more active oxygen species and thus benefited the removal reaction of formaldehyde. Simultaneously, $x \mathrm{BiOCl} / \mathrm{MnMgAlO}$ showed increased surface basicity in comparison with their parent hydrotalcites due to the perfect exposure of base sites during calcination. This favored the adsorption of reactant formaldehyde molecules and further increased the probability of formaldehyde removal by oxidation, which also contributed to their efficient catalytic performance. Furthermore, $\mathrm{xBiOCl} / \mathrm{MnMgAlO}$ showed excellent stability and potential application prospect.

Author Contributions: X.W., G.W. and Y.M. designed the experiments; X.W. and G.W. performed the experiments; X.W. analyzed the data and wrote the paper. All authors have read and agreed to the published version of the manuscript.

Funding: This research was funded by the Key Research and Development Program of Jiangsu Province [grant numbers BE2018718] and the Open Research fund of Key Laboratory for Organic Electronics and Information Displays.

Conflicts of Interest: No conflict of interest was declared here.

\section{References}

1. Salthammer, T.; Mentese, S.; Marutzky, R. Formaldehyde in the indoor environment. Chem. Rev. 2010, 110, 2536-2572. [CrossRef]

2. Hakim, M.; Broza, Y.Y.; Barash, O.; Peled, N.; Phillips, M.; Amann, A.; Haick, H. Volatile organic compounds of lung cancer and possible biochemical pathways. Chem. Rev. 2012, 112, 5949-5966. [CrossRef] [PubMed]

3. Wenger, O.S. Vapochromism in organometallic and coordination complexes: Chemical sensors for volatile organic compounds. Chem. Rev. 2013, 113, 3686-3733. [CrossRef]

4. Bai, B.Y.; Qiao, Q.; Li, J.H.; Hao, J.M. Progress in research on catalysts for catalytic oxidation of formaldehyde. Chin. J. Catal. 2016, 37, 102-122. [CrossRef]

5. Torres, J.Q.; Royer, S.; Bellat, J.P.; Giraudon, J.M.; Lamonier, J.F. Formaldehyde: Catalytic oxidation as a promising soft way of elimination. ChemSusChem 2013, 6, 578-592. [CrossRef] [PubMed]

6. Huang, H.B.; Xu, Y.; Feng, Q.Y.; Leung, D.Y.C. Low temperature catalytic oxidation of volatile organic compounds: A review. Catal. Sci. Technol. 2015, 5, 2649-2669. [CrossRef] 
7. Nie, L.H.; Yu, J.G.; Jaroniec, M.; Tao, F.F. Room-temperature catalytic oxidation of formaldehyde on catalysts. Catal. Sci. Technol. 2016, 6, 3649-3669. [CrossRef]

8. Zhang, Y.P.; Mo, J.H.; Li, Y.G.; Sundell, J.; Wargocki, P.; Zhang, J.; Little, J.C.; Corsi, R.; Deng, Q.H.; Leung, M.H.K.; et al. Can commonly-used fan-driven air cleaning technologies improve indoor air quality? A literature review. Atmos. Environ. 2011, 45, 4329-4343. [CrossRef]

9. Chen, M.H.; Qin, Y.P.; Wang, W.Z.; Li, X.Y.; Wang, J.J.; Wen, H.; Yang, Z.Q.; Wang, P. Engineering oxygen vacancies via amorphization in conjunction with $\mathrm{W}$-doping as an approach to boosting catalytic properties of $\mathrm{Pt} / \mathrm{Fe}-\mathrm{W}$-O for formaldehyde oxidation. J. Hazar. Mater. 2021, 416, 126224. [CrossRef]

10. Yang, T.F.; Huo, Y.; Liu, Y.; Rui, Z.B.; Ji, H.B. Efficient formaldehyde oxidation over nickel hydroxide promoted $\mathrm{Pt} / \gamma-\mathrm{Al}_{2} \mathrm{O}_{3} \mathrm{with}$ a low Pt content. Appl. Catal. B Environ. 2017, 200, 543-551. [CrossRef]

11. Tan, H.Y.; Wang, J.; Yu, S.Z.; Zhou, K.B. Support morphology-dependent catalytic activity of Pd/CeO 2 for formaldehyde oxidation Environ. Sci. Technol. 2015, 49, 8675-8682. [CrossRef] [PubMed]

12. Ye, J.W.; Cheng, B.; Wageh, S.; Al-Ghamdib, A.A.; Yu, J.G. Flexible Mg-Al layered double hydroxide supported Pt on Al foil for use in room-temperature catalytic decomposition of formaldehyde. RSC Adv. 2016, 6, 34280-34287. [CrossRef]

13. Chen, Y.X.; Huang, Z.W.; Zhou, M.J.; Hu, P.P.; Du, C.T.; Kong, L.D.; Chen, J.M.; Tang, X.F. The active sites of supported silver particle catalysts in formaldehyde oxidation. Chem. Commun. 2016, 52, 9996-9999. [CrossRef] [PubMed]

14. Xu, Z.H.; Yu, J.G.; Jaroniec, M. Efficient catalytic removal of formaldehyde at room temperature using AlOOH nanoflakes with deposited P. Appl. Catal. B Environ. 2015, 163, 306-312. [CrossRef]

15. Li, Y.B.; Wang, C.Y.; Zhang, C.B.; He, H. Formaldehyde oixidation on $\mathrm{Pd} / \mathrm{TiO}_{2}$ catalysts at room temperature: The effects of surface oxygen vacancies. Top. Catal. 2020, 63, 810-816. [CrossRef]

16. Lin, M.Y.; Yu, X.L.; Yang, X.Q.; Ma, X.Y.; Ge, M.F. Exploration of the active phase of the hydrotalcite-derived cobalt catalyst for HCHO oxidation. Chin. J. Catal. 2019, 40, 703-712. [CrossRef]

17. Qi, Y.Q.P.; Zhang, W.R.; Zhang, Y.S.; Bai, G.M.; Wang, S.W.; Liang, P. Formaldehyde oxidation at room temperature over layered $\mathrm{MnO}_{2}$. Catal. Commun. 2021, 153, 106293. [CrossRef]

18. Ma, C.; Sun, S.; Lu, H.; Hao, Z.; Yang, C.G.; Wang, B.; Chen, C.; Song, M.Y. Remarkable $\mathrm{MnO}_{2}$ structure-dependent $\mathrm{H}_{2} \mathrm{O}$ promoting effect in HCHO oxidation at room temperature. J. Hazar. Mater. 2021, 414, 125542. [CrossRef]

19. Tao, Y.; Li, R.; Huang, A.B.; Ma, Y.N.; Ji, S.D.; Jin, P.; Luo, H.J. High catalytic activity for formaldehyde oxidation of an interconnected network structure composed of d- $\mathrm{MnO}_{2}$ nanosheets and c-MnOOH nanowires. Adv. Manuf. 2020, 8, 429-439. [CrossRef]

20. Wang, Z.; Wang, W.Z.; Zhang, L.; Jiang, D. Surface oxygen vacancies on $\mathrm{Co}_{3} \mathrm{O}_{4}$ mediated catalytic formaldehyde oxidation at room temperature. Catal. Sci. Technol. 2016, 6, 3845-3853. [CrossRef]

21. Lu, S.H.; Li, K.L.; Huang, F.L.; Chen, C.C.; Sun, B. Efficient $\mathrm{MnO}_{\mathrm{x}}-\mathrm{Co}_{3} \mathrm{O}_{4}-\mathrm{CeO}_{2}$ catalysts for formaldehyde elimination. Appl. Surf. Sci. 2017, 400, 277-282. [CrossRef]

22. Bai, L.; Wyrwalski, F.; Safariamin, M.; Bleta, R.; Lamonier, J.F.; Przybylski, C.; Monflier, E.; Ponchel, A. Cyclodextrin-cobalt (II) molecule-ion pairs as precursors to active $\mathrm{Co}_{3} \mathrm{O}_{4} / \mathrm{ZrO}_{2}$ catalysts for the complete oxidation of formaldehyde: Influence of the cobalt source. J. Catal. 2016, 341, 191-204. [CrossRef]

23. Huang, Y.C.; Fan, W.J.; Long, B.; Li, H.B.; Qiu, W.T.; Zhao, F.Y.; Tong, Y.X.; Ji, H.B. Alkali-modified non-precious metal 3D-NiCo $2 \mathrm{O}_{4}$ nanosheets for efficient formaldehyde oxidation at low temperature. J. Mater. Chem. A 2016, 4, 3648-3654. [CrossRef]

24. Dai, Z.J.; Yu, X.W.; Huang, C.; Li, M.; Su, J.F.; Guo, Y.P.; Xu, H.; Ke, Q.F. Nanocrystalline $\mathrm{MnO}_{2}$ on an activated carbon fiber for catalytic formaldehyde removal. RSC Adv. 2016, 6, 97022-97029. [CrossRef]

25. Rong, S.P.; Zhang, P.Y.; Wang, J.L.; Liu, F.; Yang, Y.J.; Yang, G.L.; Liu, S. Ultrathin manganese dioxide nanosheets for formaldehyde removal and regeneration performance. Chem. Eng. J. 2016, 306, 1172-1179. [CrossRef]

26. Bai, B.Y.; Qiao, Q.; Li, J.H.; Ha, J.M. Synthesis of three-dimensional ordered mesoporous $\mathrm{MnO}_{2}$ and its catalytic performance in formaldehyde oxidation. Chin. J. Catal. 2016, 37, 27-31. [CrossRef]

27. Bai, B.Y.; Qiao, Q.; Arandiyan, H.; Li, J.H.; Hao, J.M. Three-dimensional ordered mesoporous $\mathrm{MnO}_{2}$ supported Ag nanoparticles for catalytic removal of formaldehyde. Environ. Sci. Technol. 2016, 50, 2635-2640. [CrossRef]

28. Zhu, L.; Wang, J.L.; Rong, S.P.; Wang, H.Y.; Zhang, P.Y. Cerium modified birnessite-type $\mathrm{MnO}_{2}$ for gaseous formaldehyde oxidation at low temperature. Appl. Catal. B Environ. 2017, 211, 212-221. [CrossRef]

29. Huang, Y.X.; Ye, K.H.; Li, H.B.; Fan, W.J.; Zhang, Y.M.; Ji, H.B. A highly durable catalysts based on Co $\mathrm{o}_{\mathrm{x}} \mathrm{Mn}_{3-\mathrm{x}} \mathrm{O}_{4}$ nanosheets for low-temperature formaldehyde oxidation. Nano Res. 2016, 9, 3881-3892. [CrossRef]

30. Peña O'Shea, V.A.; Álvarez-Galván, M.C.; Fierro, J.L.G.; Arias, P.L. Influence of feed composition on the activity of Mn and $\mathrm{PdMn} / \mathrm{Al}_{2} \mathrm{O}_{3}$ catalysts for combustion of formaldehyde/methanol. Appl. Catal. B Environ. 2005, 57, 191-199. [CrossRef]

31. Li, H.; Qin, F.; Yang, Z.; Cui, X.; Wang, J.; Zhang, L. New reaction pathway induced by plasmon for selective benzyl alcohol oxidation on BiOCl possessing oxygen vacancies. J. Am. Chem. Soc. 2017, 139, 3513-3521. [CrossRef] [PubMed]

32. Ning, X.; Li, Y.; Yu, H.; Peng, F.; Wang, H.; Yang, Y. Promoting role of bismuth and antimony on Pt catalysts for the selective oxidation of glycerol to dihydroxyacetone. J. Catal. 2016, 335, 95-104. [CrossRef]

33. Wang, X.L.; Wu, G.D.; Zhang, X.L.; Wang, D.F.; Lan, J.Y.; Li, J.Y. Selective oxidation of glycerol to glyceraldehyde with $\mathrm{H}_{2} \mathrm{O}_{2}$ catalyzed by $\mathrm{CuNiAl}$ hydrotalcites supported BiOCl in Neutral Media. Catal. Lett. 2019, 149, 1046-1056. [CrossRef] 
34. Cavani, F.; Trifiro, F.; Vaccari, A. Hydrotalcite-type anionic clays: Preparation, properties and applications. Catal. Today 1991, 11, 173-301. [CrossRef]

35. Labajos, F.M.; Rives, V.; Ulibarri, M.A. Effect of hydrothermal and thermal treatments on the physicochemical properties of Mg-Al hydrotalcite-like materials. J. Mater. Sci. 1992, 27, 1546-1552. [CrossRef]

36. Yan, Z.X.; Xu, Z.H.; Cheng, B.; Jiang, C.J. $\mathrm{Co}_{3} \mathrm{O}_{4}$ nanorod-supported Pt with enhanced performance for catalytic $\mathrm{HCHO}$ oxidation at room temperature. Appl. Surf. Sci. 2017, 404, 426-434. [CrossRef]

37. Prescott, H.A.; Li, Z.J.; Kemnitz, E.; Trunschke, A.; Deutsch, J.; Lieske, H.; Auroux, A. Application of calcined Mg-Al hydrotalcites for Michael additions: An investigation of catalytic activity and acid-base properties. J. Catal. 2005, 234, 119-130. [CrossRef]

38. Wu, G.D.; Wang, X.L.; Chen, B.; Li, J.P.; Zhao, N.; Wei, W.; Sun, Y.H. Fluorine-modified mesoporous Mg-Al mixed oxides: Mild and stable base catalysts for O-methylation of phenol with dimethyl carbonate. Appl. Catal. A Gen. 2007, 329, 106-111. [CrossRef]

39. Li, H.; Li, J.; Jia, F.L.; Zhang, L.Z. Oxygen vacancy-mediated photocatalysis of BiOCl: Reactivity, selectivity, and perspectives. Angew. Chem. Int. Ed. 2017, 56, 2-19. [CrossRef]

40. Wu, G.D.; Wang, X.L.; Wei, W.; Sun, Y.H. Fluorine-modified mesoporous Mg-Al mixed oxides: A solid base with variable basic sites and tunable basicity. Appl. Catal. A Gen. 2010, 377, 107-113. [CrossRef]

41. Ishikawa, S.; Goto, Y.; Kawahara, Y.; Inukai, S.; Hiyoshi, N.; Dummer, N.F.; Murayama, T.; Yoshida, A.; Sadakane, M.; Ueda, W. Synthesis of crystalline microporous Mo-V-Bi oxide for selective oxidation of light alkanes. Chem. Mater. 2017, 29, 2939-2950. [CrossRef]

42. Xia, Y.T.; Wang, J.L.; Gu, C.Q.; Ling, Y.; Gao, Z.M. $\mathrm{MnO}_{2} / \mathrm{Al}$ foil decorated air cleaner with self-driven property for the abatement of indoor formaldehyde. Chem. Eng. J. 2020, 382, 122872. [CrossRef]

43. Zou, N.; Nie, Q.; Zhang, X.R.; Zhang, G.K.; Wang, J.L.; Zhang, P.Y. Electrothermal regeneration by Joule heat effect on carbon cloth based $\mathrm{MnO}_{2}$ catalyst for long-term formaldehyde removal. Chem. Eng. J. 2019, 357, 1-10. [CrossRef] 